\title{
Evaluation of Customized Fertilizers in Respect to Yield, Soil Nutrients Status, Uptake and Economics of Wheat (Triticum aestivum L.) under Eastern Uttar Pradesh
}

\author{
Anand Singh ${ }^{1}$, Neeraj Kumar ${ }^{2}$, U.P. Shahi ${ }^{1}$, Bhavya Raj Pandey ${ }^{2}$, \\ Pramod Kumar ${ }^{2}$, Prashant Deo Singh ${ }^{1}$ and R.P. Singh ${ }^{2}$ \\ ${ }^{1}$ Soil Science \& Agriculture Chemistry, SVPUAT, Meerut, India \\ ${ }^{2}$ Soil Science \& Agriculture Chemistry, NDUAT, Faizabad, India \\ ${ }^{5}$ CSAUAT, Kanpur, India \\ *Corresponding author
}

\section{Keywords}

Micro nutrient,

TCL, Indo-Gulf, ppm, Soil health

Article Info

Accepted:

10 February 2019

Available Online:

10 March 2019

\section{A B S T R A C T}

Today the application of imbalance fertilizers is an important issue for both crop productivity and soil health. The use of macro nutrients fertilizers increasing in both amount and numbers of application but in respect of it use of micro nutrients fertilizers decreasing. A reason behind this is to apply different type of fertilizers for different macro and micro nutrients. Therefore, the research work was proposed to study the scope of customized fertilizer (a combination of macro and micro nutrients) for increasing the productivity of wheat. Field experiment was carried out in randomized block design with four replications and the treatment consisted of $T_{1}$ (control), $T_{2}$ (RDF), $T_{3}$ (Soil test-based recommendation), $\mathrm{T}_{4}$ (Indo-Gulf Customized Fertilizer), $\mathrm{T}_{5}$ (TCL Customized Fertilizer) and $\mathrm{T}_{6}$ (Farmer's Practice). The treatment effect was compared based on yield, soil nutrients status, uptake and economics of crop. The grain and straw yield $\left(\mathrm{q} \mathrm{ha}^{-1}\right)$, uptake of nitrogen, phosphorus, potassium, sulphur, zinc and boron were maximum under $\mathrm{T}_{3}$, which was at par with $T_{4}$ and $T_{5}$ and significantly superior over $T_{1}, T_{2}$ and $T_{6}$. The maximum grain yield of wheat $\left(46.64 \mathrm{q} \mathrm{ha}^{-1}\right)$ was recorded with $\mathrm{T}_{3}$ which was significantly higher over than $\mathrm{T}_{1}\left(20.08 \mathrm{q} \mathrm{ha}^{-1}\right), \mathrm{T}_{6}\left(30.78 \mathrm{q} \mathrm{ha}^{-1}\right)$ and $\mathrm{T}_{2}\left(38.10 \mathrm{q} \mathrm{ha}^{-1}\right)$ while at par with $\mathrm{T}_{5}\left(43.92 \mathrm{q} \mathrm{ha}^{-1}\right)$ and $\mathrm{T}_{4}\left(44.97 \mathrm{q} \mathrm{ha}^{-1}\right)$. Maximum net return (Rs. $\left.43828 \mathrm{ha}^{-1}\right)$ and $\mathrm{B}: \mathrm{C}(0.95)$ were calculated in $\mathrm{T}_{3}$ followed by $\mathrm{T}_{4}$ (net return Rs. $39078 \mathrm{ha}^{-1}$ and B:C 0.82) and $\mathrm{T}_{5}$ (net return Rs. $36925 \mathrm{ha}^{-1}$ and $\mathrm{B}: \mathrm{C}$ 0.78). Thus, from the finding we can say that the customized fertilizers will increase the yield, uptake of nutrients and also sustained the soil health by supplying the micro nutrient along with the macronutrients.

\section{Introduction}

Wheat (Triticum spp.) is the most important cereal crops in the world. It is grown in a wide range of environments around the world and it also has the highest adaptation among all the crop species. Wheat belongs to family Poaceae (Gramineae). India has achieved selfsufficiency in food production at present, but the realistic demand for food has been 
estimated at 301.08 million tons for 2020, which will reach 330.18 million tons by the year 2030 (Goyal and Singh 2002). About $91 \%$ of the total wheat production is contributed by northern states. India is one of the principal wheat producing and consuming country in the world.

Worldwide more land is devoted to the production of wheat than any other contributes about $60 \%$ of daily protein requirement and more calories to world human diet than any other food crops (Mattean et al., 1970). It contains more protein than other cereals. Wheat has relatively high content of niacin and thymine. Wheat protein gluten is very essential for bakers. Flour of other cereals lacking gluten is therefore not good for bread making. It is consumed mostly in the form of chapatti. Wheat straw is used for feeding the cattle. Due to very intensive agriculture involving exhaustive high yielding varieties of cereals particularly, wheat has led to heavy withdrawal of nutrients from the soil. This resulted in the increase in consumption of chemical fertilizers, but the trend of fertilizer use efficiency is not encouraging. These erratic fertilizer use patterns, if continued for years, could cause much greater drain on native soil fertility and the soil may not be able to support high production levels in future. Therefore, in the event of nutrient turnover in soil-plant system being considerably high under intensive farming, neither chemical fertilizer nor organic/biological sources alone can achieve production sustainability. The rice - wheat cropping system involving high yielding varieties even with recommended dose of $\mathrm{N}, \mathrm{P}$ and $\mathrm{K}$ use, impoverishing soils in secondary and micro nutrients especially $\mathrm{S}, \mathrm{Zn}, \mathrm{Mn}, \mathrm{B}$ and Fe. The deficiencies of $\mathrm{Zn}, \mathrm{S}$ and other micronutrients was resulting due to use of high analysis fertilizers and inadequate addition of organic manures (Patel and Singh, 2010). Nearly $50 \%$ of the world soils used for cereal production is $\mathrm{Zn}$ deficient (Gibbson, 2006). The results of large number of experiments clearly showed that even recommended rates of NPK application based on soil test basis, the yield of crops or of the cropping system could not be maintained at higher level continuously (Ananda and Patil, 2005). The deficiency of $\mathrm{S}, \mathrm{Zn}$ and Fe or $\mathrm{Mn}$ becoming a limiting factor for crop yield (Rekhi et al., 2000). The decrease in productivity was observed to be associated with the new emerging problems of deficiency of micronutrients such as zinc ( $\mathrm{Zn}$ ) and of secondary nutrients such as sulphur $(\mathrm{S})$. The minimal deleterious effect on environment as well as soil with balance nutrient supply to the crops (Hegde et al., 2007). The 'Customized Fertilizer' made up of mixing Nitrogen, Phosphorus, Potassium, Sulphur and Zinc has been tested for enhancing wheat yield. Customized fertilizers may be describe as an unique and ready to use granulated fertilizers, formulated on sound scientific plant nutrition principles integrated with soil information, extensive laboratory studies and it is evaluated through field research (Rakshit et al., 2012). The Central Fertilizer Committee has included customized fertilizers in the Fertilizer (Control) Order (FCO) 1985, as a new category of fertilizers that are area, soil and crop specific. Customized fertilizers are crop, soil and area specific and a good promise to maintained soil health by ensuring appropriate fertilization. Being a combination of macro and micro nutrients it facilitate the application of the complete range of plant nutrients in the right proportion and to suit the specific requirement of a crop at different stages of growth and these are more relevant under site specific nutrient management practices. There are number of companies and they are producing a large number of customized fertilizer grades have included in fertilizer control order which are multi-nutrient carriers designed to contain macro and micro nutrients. A systematic process of granulation 
providing uniform quality and can meet crop nutritional needs which is specific to site, soil and stage of crop. Maintenance of proper soil fertility in Rice-wheat system is formidable challenge.

\section{Materials and Methods}

\section{Experimental site}

A Field experiment was carried out during Rabi season of 2015-2016 at Agronomy Research Farm of Narendra Deva University of Agriculture and Technology, Kumarganj, Faizabad (U.P.). Geographically, this experimental site falls under semi-arid, subtropical climate of Indo-Gangatic alluvial plains (IGP) having alluvial calcareous soil and is located at $26^{\circ} 47^{\prime \prime} \mathrm{N}$ latitude and $82^{\circ} 12^{\prime \prime}$ E longitude on an elevation of about 113 meters above mean sea level. The average annual precipitation is about $1150 \mathrm{~mm}$ of which 80-85 per cent is received during monsoon period i.e., between June to September. The total rainfall during course of experimentation was $4.8 \mathrm{~mm}$. The soil of experimental field was silt loam texture, low in organic carbon $(0.38 \%)$ and low in available nitrogen (151.76 $\left.\mathrm{kg} \mathrm{ha} \mathrm{ha}^{-1}\right)$, phosphorus (14.75 kg ha-1) and medium in potassium (248.00 $\left.\mathrm{kg} \mathrm{ha}^{-1}\right)$ and low in sulphur $\left(9.00 \mathrm{~kg} \mathrm{ha}^{-1}\right)$, zinc $(0.50 \mathrm{ppm})$ and boron (0.46ppm).

\section{Experimental design and treatments}

The experiment was laid out in randomized block design with four replications. The treatment consisted of $\mathrm{T}_{1}$ (control), $\mathrm{T}_{2}$ (RDF), $\mathrm{T}_{3}$ (Soil test-based recommendation), $\mathrm{T}_{4}$ (IndoGulf Customized Fertilizer), $\mathrm{T}_{5}$ (TCL Customized Fertilizer) and $\mathrm{T}_{6}$ (Farmer's Practice).The crop was sown on 3 December 2015. The crop was fertilized according to treatments in which $\mathrm{T}_{1}$ was completely control, $\mathrm{T}_{2}$ with recommended dose of $\mathrm{N}: \mathrm{P}: \mathrm{K}$ (150:60:40), $\mathrm{T}_{3}$ (N:P:K 120:60:30, S:Zn:B
30:5:2), and $\mathrm{T}_{6}$ (N:P:K 100:40:0). The half dose of $\mathrm{N}$ and full dose of $\mathrm{P}_{2} \mathrm{O}_{5}$ and $\mathrm{K}_{2} \mathrm{O}$ with urea DAP and MOP were applied at time of sowing. In treatment $T_{3}$ sulphur, zinc and boron were applied through gypsum, zinc sulphate and borax, respectively. The crop was harvested at 140 days after sowing and yield was recorded.

\section{Yield of wheat}

Yield attributes like number of grains per spike and 1000-grain weight were measured by harvesting five plant samples per plot selected at random. The wheat crop was harvested at maturity, then the grain and straw yield was recorded.

\section{Soil and plant analysis}

The soil samples $(0-15 \mathrm{~cm})$ were collected randomly from each plot after wheat harvest for determination of soil $\mathrm{pH}$, electrical conductivity, organic carbon, N, P, K, S, Zn and $\mathrm{B}$ content in the surface soil. The standard procedures were obtained for analysis of soil samples. The plant samples collected at harvest were analysed for nitrogen, phosphorus, potassium, sulphur, zinc and boron content and there by calculated the uptake of these nutrients by grain and straw.

\section{Economics and statistical analysis}

Cost of cultivation for different treatments were worked out by considering all the expense incurred in the cultivation of experimental crop and added with variable cost due to treatments. The data recorded on different characters during the course of investigation were subjected to statistical analysis by using the analysis of variance technique Panse and Sukhatme (1967). The treatment differences were tested by ' $F$ ' test significance comparing the calculated variance ratio ( $F$ value). If $F$ values were found to be significant at $5 \%$ level of significance, critical 
differences were calculated to compare the significant differences between the treatments.

\section{Results and Discussion}

\section{Yield and harvest index}

Yield is the result of cumulative response of yield contributing characters which are determine from the growth and development traits and presented in Table 1. The maximum grain yield of wheat (46.64 $\left.\mathrm{qha}^{-1}\right)$ was obtained underT $T_{3}$ (Soil test-based recommendation) treatment which was significantly superior over $\mathrm{T}_{1}$-control (20.08 $\left.\mathrm{qha}^{-1}\right), \mathrm{T}_{6}$-farmer's Practices (30.78 $\mathrm{qha}^{-1}$ ) and $\mathrm{T}_{2}-\operatorname{RDF}\left(38.10 \mathrm{qha}^{-1}\right)$ while, at par withT $4^{-}$ Indo-Gulf Customized Fertilizer (44.97 $\mathrm{qha}^{-1}$ ) and $\mathrm{T}_{5}$-TCL Customized Fertilizer (43.92 q $\left.\mathrm{ha}^{-1}\right)$. The minimum grain yield $\left(20.08 \mathrm{qha}^{-1}\right)$ of wheat was found in treatment $\mathrm{T}_{1}$-control. The maximum straw yield (73.30 $\left.\mathrm{qha}^{-1}\right)$ of wheat was obtained under the treatment $T_{3}$ (Soil test-based recommendation) which was significantly superior over all the treatments except $\mathrm{T}_{4}$-Indo-Gulf Customized Fertilizer (70.96 $\mathrm{qha}^{-1}$ ) and $\mathrm{T}_{5}$-TCL Customized Fertilizer (68.86 $\left.\mathrm{qha}^{-1}\right)$. The higher grain yield may be owing to the application of enough nutrients in combination which resulted to greater availability of essential nutrients to plants, improvement of soil environment which facilitate in better root proliferation leading to higher absorption of water and nutrients and ultimately resulting in higher yield. The extent of increase in grain and straw yield may be dependent on the effect of soil test-based recommendation and use of customized fertilizers. Shekhon et al., (2012) also reported that application of higher dose of customized fertilizer produced additional grain and straw yields. Goswami (2007) and Singh et al., (2012) reported that addition of micronutrient and secondary nutrient increased wheat yield. Reddy et al., (2009) and Mandal et al., (2004) also reported superiority of combined application of $\mathrm{N}, \mathrm{P}$, $\mathrm{K}, \mathrm{Zn}$ and FYM over recommended fertilizer application. Similar results were also reported by Dwivedi et al., (2014), Meena et al., (2013), Khan et al., (2008), Chopra et al., (2016) and Chauhan et al., (2013).

The highest harvest index (38.94\%) was calculated with $\mathrm{T}_{5}$. However, minimum harvest index $(37.77 \%)$ with control. The respective values of harvest index were calculated $37.77 \%, 38.43 \%, 38.88 \%, 38.79 \%$, $38.94 \%$ and $38.21 \%$ with the treatments $\mathrm{T}_{1}$, $\mathrm{T}_{2}, \mathrm{~T}_{3}, \mathrm{~T}_{4}, \mathrm{~T}_{5}$ and $\mathrm{T}_{6}$. In general, the values of harvest index were slightly differing under most of the treatments. Harvest index is a function of economic yield to biological yield (Black and Watson, 1960) (Fig. 1 and Table 2).

\section{Organic carbon}

The maximum organic carbon content in soil was found in treatment $\mathrm{T}_{3}$-Soil test-based recommendation $\left(0.42 \mathrm{gkg}^{-1}\right)$ followed by $\mathrm{T}_{4}-$ Indo-Gulf Customized Fertilizer $\left(0.41 \mathrm{gkg}^{-1}\right)$ and $\mathrm{T}_{5}-\mathrm{TCL}$ Customized Fertilizer $(0.40 \mathrm{~g}$ $\left.\mathrm{kg}^{-1}\right)$. This increase in organic carbon might be due to improvement in root and shoot growth and thus higher production biomass, which in turn, increased the organic carbon content in soil after decay (Sabina Ahmed et al 2014). Manna et al., (2016) reported that over the course of time the application of nalon decreased total organic carbon by $20.4 \%$, whereas addition of balanced NPK doses either maintain or enhanced as compared to initial value. Similar result was found in research of Rather et al., (2009), Eldardiry et al., (2013), Singh et al., (2004)

\section{Available N, P, K}

The maximum available $\mathrm{N}\left(177.90 \mathrm{kgha}^{-1}\right)$ was observed in treatment $\mathrm{T}_{2}(\mathrm{RDF}), \mathrm{P}$ (19.76 $\mathrm{kgha}^{-1}$ ) in $\mathrm{T}_{4}$ (Indo-Gulf Customized fertilizer) 
and $\mathrm{K}\left(257.72 \mathrm{kgha}^{-1}\right)$ in $\mathrm{T}_{5}$ (TCL-Customized fertilizer) were observed under treatment $\mathrm{T}_{3}$ (Soil test-based recommendation) (Fig. 2). While minimum available amount of $\mathrm{N}\left(138.12 \mathrm{kgha}^{-1}\right), \mathrm{P}\left(12.78 \mathrm{kgha}^{-1}\right), \mathrm{K}$ (228.75 $\left.\mathrm{kgha}^{-1}\right)$ were observed under treatment $\mathrm{T}_{1}$ (Control). The improvement in the status of available $\mathrm{N}, \mathrm{P}$, and $\mathrm{K}$ in soil after harvest of the crop was due to addition of these nutrients through the application of chemical and customized fertilizers. Related to above results some other findings were found in some other research that is Rather et al., (2009) and Singh (2017).

\section{Available S, Zn and B}

The maximum $\mathrm{S}$ (15.87 $\left.\mathrm{kgha}^{-1}\right), \mathrm{Zn}(0.69$ ppm) and B (0.58 ppm) content in soil were observed under treatment $\mathrm{T}_{3}$ (Soil test-based recommendation). While minimum content of S (7.90 kgha $\left.{ }^{-1}\right), \mathrm{Zn}\left(0.50 \mathrm{gha}^{-1}\right)$ and B (0.40 gha $\left.^{-1}\right)$ in soil were recorded under treatment $T_{1}$ (Control). The availability of S depends on the solubilisation and mineralization process. When the availability of $\mathrm{Zn}$ and $\mathrm{B}$ increases the efficiency of primary and secondary nutrients $(\mathrm{N}, \mathrm{P}, \mathrm{K}$, and $\mathrm{S})$ were also enhanced. In soil test-based recommendation, the $S, Z n$ and B containing fertilizers were also applied separately, so its availability in this treatment was increased. Available $\mathrm{S}$ and $\mathrm{Zn}$ status of the soil reduced in the soil from their initial status in $\mathrm{S}$ and $\mathrm{Zn}$ free treatments (Barthwal et al., 2013). Similar result was also reported by Ahmed et al., (2014) (Fig. 3).

\section{Uptake of $\mathbf{N}, \mathbf{P}$ and $\mathrm{K}$}

The nitrogen is mainly responsible for vegetative growth of plants. In all the three macro nutrients the uptake of potassium was maximum by crop because it involves in translocation process and in a plant its maximum amount was found in wheat straw than seed. Phosphorus is essential for root growth and seed filling process, so its maximum amount was found in wheat seed than straw. The maximum uptake of $\mathrm{N}$ $\left(115.92 \mathrm{kgha}^{-1}\right), \quad \mathrm{P}\left(33.39 \mathrm{kgha}^{-1}\right)$ and $\mathrm{K}$ $\left(127.23 \mathrm{kgha}^{-1}\right)$ were observed under treatment $\mathrm{T}_{3}$ (Soil test-based recommendation). While minimum uptake of $\mathrm{N}\left(43.76 \mathrm{kgha}^{-1}\right), \mathrm{P}$ (10.79 $\mathrm{kgha}^{-1}$ ) and $\mathrm{K}$ (52.30 $\left.\mathrm{kgha}^{-1}\right)$, were observed under $\mathrm{T}_{1}$ (Control). The uptake of potassium is more in wheat straw than seed. The phosphorus uptake by crop is less in comparison to other macronutrients due to its low availability in soil. The higher nutrient uptake was mainly due to higher biological (straw + grain) yield. Pandey et al., (2007) also reported similar findings. Application of customized fertilizer helps to provide essential nutrient to get the targeted yield. This shows that NPKS and Zn combination is useful for wheat growth and yield. Singh (2006) and Das et al., (2003) also reported similar findings for NPKS and Zn (Fig. 4).

\section{Uptake of S, Zn and B}

The maximum uptake S (76.47 $\left.\mathrm{kgha}^{-1}\right), \mathrm{Zn}$ (223.07 $\left.\mathrm{gha}^{-1}\right)$ and B (60.85 $\left.\mathrm{gha}^{-1}\right)$, were observed under treatment $\mathrm{T}_{3}$ (Soil test-based recommendation). While minimum uptake of S (30.82 $\left.\mathrm{kgha}^{-1}\right), \mathrm{Zn}\left(85.01 \mathrm{gha}^{-1}\right)$ and B (42.10 gha $\left.^{-1}\right)$, were observed under $\mathrm{T}_{1}$ (Control). The higher nutrient uptake was mainly due to higher biological (straw + grain). Nutrients uptake by crop is mainly a function of crop yield and nutrient concentration in grain and straw. The concentration of nutrients also increases due to NPKS and $\mathrm{Zn}$ customized fertilizer because of improved nutrition environment in rhizosphere and consequently in plant system (Dewal and Pareek, 2014). Choudhary et al., (2014) was also concluded that application of $\mathrm{S}$ and $\mathrm{Zn}$ improve the yield and quality traits of crop. Similar results were obtained by Scotta (1986) and Milapchand (1969). Biswas et al., (2015) reported that application of one micronutrient might have 
accelerated the uptake of other micro and macro nutrients (such as $\mathrm{B}, \mathrm{Zn}, \mathrm{N}, \mathrm{P}$ and $\mathrm{K}$ ) resulting in higher yield. Similar results were also found in research of Singh (2016) and Dwivedi et al., (2014) (Fig. 5 and Table 3).

\section{Economics}

The maximum cost of cultivation incurred under the treatments $\mathrm{T}_{4}$ and $\mathrm{T}_{5}\left(\right.$ Rs. $\left.47416 \mathrm{ha}^{-1}\right)$. While minimum cost of cultivation was calculated under treatment $\mathrm{T}_{1}$ (Rs. $36530 \mathrm{ha}^{-1}$ ).

Table.1 Effect of various treatments on grain yield, straw yield and harvest index of wheat

\begin{tabular}{|c|c|c|c|c|}
\hline S.No. & Treatments & $\begin{array}{l}\text { Grain yield (q } \\
\left.\text { ha }^{-1}\right)\end{array}$ & $\begin{array}{l}\text { Straw yield }(q \\
\left.\text { ha }^{-1}\right)\end{array}$ & Harvest index \\
\hline $\mathbf{T}_{1}$ & Control (No fertilizer) & 20.08 & 33.07 & 37.77 \\
\hline $\mathbf{T}_{2}$ & Recommended dose of Fertilizer & 38.10 & 61.03 & 38.43 \\
\hline $\mathbf{T}_{3}$ & $\begin{array}{l}\text { Soil test-based recommendation } \\
\text { (NPKSZnB) }\end{array}$ & 46.64 & 73.30 & 38.88 \\
\hline $\mathbf{T}_{4}$ & $\begin{array}{l}\text { IndoGulf-Customized Fertilizer- } \\
\text { Vardan }\end{array}$ & 44.97 & 70.96 & 38.79 \\
\hline $\mathbf{T}_{5}$ & TCL-Customized Fertilizer-Paras & 43.92 & 68.86 & 38.94 \\
\hline \multirow[t]{3}{*}{$T_{6}$} & Farmer's Practice & 30.78 & 49.76 & 38.21 \\
\hline & SEm \pm & 2.13 & 3.16 & - \\
\hline & C.D. $(P=0.05)$ & 5.66 & 9.02 & - \\
\hline
\end{tabular}

Table.2 Effect of various treatments on organic carbon, available N, P, K, S, Zn and B at harvest of wheat

\begin{tabular}{|c|c|c|c|c|c|c|c|c|}
\hline S.No. & Treatments & $\begin{array}{l}\text { Organic } \\
\text { carbon } \\
(\%)\end{array}$ & $\begin{array}{l}\text { Nitrogen } \\
\left(\text { kgha }^{-1}\right)\end{array}$ & $\begin{array}{l}\text { Phosphorus } \\
\left(\text { kgha }^{-1}\right)\end{array}$ & $\begin{array}{l}\text { Potassium } \\
\left(\text { kgha }^{-1}\right)\end{array}$ & $\begin{array}{l}\text { Sulphur } \\
\left(\text { kgha }^{-1}\right)\end{array}$ & $\begin{array}{c}\text { Zinc } \\
(\mathbf{p p m})\end{array}$ & $\begin{array}{l}\text { Boron } \\
(\mathbf{p p m})\end{array}$ \\
\hline$T_{1}$ & $\begin{array}{ll}\text { Control } & \text { (No } \\
\text { fertilizer) }\end{array}$ & 0.37 & 138.12 & 12.78 & 228.75 & 7.90 & 0.50 & 0.40 \\
\hline $\mathbf{T}_{2}$ & $\begin{array}{l}\text { Recommended } \\
\text { dose of Fertilizer }\end{array}$ & 0.40 & 177.90 & 18.15 & 256.65 & 11.14 & 0.66 & 0.43 \\
\hline$T_{3}$ & $\begin{array}{l}\text { Soil test-based } \\
\text { recommendation } \\
\text { (NPKSZnB) }\end{array}$ & 0.42 & 173.20 & 18.18 & 248.64 & 15.87 & 0.69 & 0.58 \\
\hline $\mathbf{T}_{4}$ & $\begin{array}{l}\text { Indo Gulf- } \\
\text { Customized } \\
\text { Fertilizer- Vardan }\end{array}$ & 0.41 & 167.12 & 19.76 & 252.78 & 14.00 & 0.67 & 0.51 \\
\hline $\mathbf{T}_{5}$ & $\begin{array}{l}\text { TCL-Customized } \\
\text { Fertilizer-Paras }\end{array}$ & 0.40 & 168.70 & 18.00 & 257.72 & 13.12 & 0.68 & 0.50 \\
\hline \multirow[t]{3}{*}{$\mathbf{T}_{6}$} & Farmer's Practice & 0.38 & 152.12 & 14.45 & 233.40 & 7.92 & 0.51 & 0.41 \\
\hline & SEm \pm & 0.01 & 2.22 & 0.51 & 3.09 & 0.40 & 0.02 & 0.01 \\
\hline & C.D. $(\mathrm{P}=0.05)$ & 0.03 & 6.72 & 1.53 & 8.97 & 1.18 & 0.07 & 0.04 \\
\hline
\end{tabular}


Table.3 Effect of various treatments on uptake of nutrients by wheat crop

\begin{tabular}{|c|c|c|c|c|c|c|c|}
\hline $\begin{array}{l}\text { S. } \\
\text { No. }\end{array}$ & Treatments & $\begin{array}{l}\text { Nitrogen } \\
\text { uptake } \\
\text { kgha }^{-1}\end{array}$ & $\begin{array}{l}\text { Phosphorus } \\
\text { uptake } \\
\text { kgha }^{-1}\end{array}$ & $\begin{array}{l}\text { Potassium } \\
\text { uptake } \\
\text { kgha }^{-1}\end{array}$ & $\begin{array}{c}\text { Sulphur } \\
\text { uptake } \\
\left(\mathrm{kg} \mathrm{ha}^{-1}\right)\end{array}$ & $\begin{array}{c}\text { Zinc } \\
\text { uptake } \\
\left(\mathrm{gha}^{-1}\right)\end{array}$ & $\begin{array}{l}\text { Boron } \\
\text { uptake } \\
\left(\text { gha }^{-1}\right)\end{array}$ \\
\hline $\mathbf{T}_{1}$ & $\begin{array}{l}\text { Control (No } \\
\text { fertilizer) }\end{array}$ & 43.76 & 10.79 & 52.30 & 30.82 & 85.01 & 42.10 \\
\hline $\mathbf{T}_{2}$ & $\begin{array}{l}\text { Recommended } \\
\text { dose of } \\
\text { Fertilizer }\end{array}$ & 88.00 & 23.07 & 100.93 & 62.11 & 181.39 & 50.27 \\
\hline $\mathbf{T}_{\mathbf{3}}$ & $\begin{array}{l}\text { Soil test-based } \\
\text { recommendation } \\
(\mathrm{NPKSZnB})\end{array}$ & 115.92 & 33.39 & 127.23 & 76.47 & 220.07 & 60.85 \\
\hline $\mathbf{T}_{4}$ & $\begin{array}{l}\text { Indo Gulf- } \\
\text { Customized } \\
\text { Fertilizer- } \\
\text { Vardan }\end{array}$ & 109.71 & 30.90 & 120.74 & 73.64 & 214.97 & 58.20 \\
\hline $\mathbf{T}_{5}$ & $\begin{array}{l}\text { TCL- } \\
\text { Customized } \\
\text { Fertilizer-Paras }\end{array}$ & 106.32 & 28.67 & 117.55 & 71.76 & 212.32 & 56.95 \\
\hline \multirow[t]{3}{*}{$\mathbf{T}_{6}$} & $\begin{array}{l}\text { Farmer's } \\
\text { Practice }\end{array}$ & 70.16 & 18.04 & 80.43 & 49.35 & 145.02 & 48.29 \\
\hline & SEm \pm & 4.40 & 1.43 & 4.84 & 2.80 & 3.76 & 2.11 \\
\hline & C.D. $(\mathrm{P}=0.05)$ & 13.25 & 4.31 & 14.58 & 8.43 & 11.30 & 6.34 \\
\hline
\end{tabular}

Table.4 Economics of wheat affected by various treatments

\begin{tabular}{|l|l|l|l|l|l|}
\hline S.No. & Treatments & $\begin{array}{l}\text { Cost } \\
\text { cultivation } \\
(\mathbf{R s})\end{array}$ & $\begin{array}{l}\text { Gross } \\
\text { return (Rs.) }\end{array}$ & $\begin{array}{l}\text { Net return } \\
\text { (Rs) }\end{array}$ & B:C ratio \\
\hline $\mathbf{T}_{\mathbf{1}}$ & Control (No fertilizer) & 36530 & 39037 & 2507 & 0.07 \\
\hline $\mathbf{T}_{\mathbf{2}}$ & $\begin{array}{l}\text { Recommended dose of } \\
\text { Fertilizer }\end{array}$ & 42735 & 73524 & 30819 & 0.72 \\
\hline $\mathbf{T}_{\mathbf{3}}$ & $\begin{array}{l}\text { Soil test based } \\
\text { recommendation } \\
\text { (NPKSZnB) }\end{array}$ & 45790 & 89618 & 43828 & 0.95 \\
\hline $\mathbf{T}_{\mathbf{4}}$ & $\begin{array}{l}\text { Indo Gulf-Customized } \\
\text { Fertilizer- Vardan }\end{array}$ & 47416 & 86495 & 39078 & 0.82 \\
\hline $\mathbf{T}_{\mathbf{5}}$ & $\begin{array}{l}\text { TCL-Customized } \\
\text { Fertilizer-Paras }\end{array}$ & 47416 & 84342 & 36926 & 0.78 \\
\hline $\mathbf{T}_{\mathbf{6}}$ & \begin{tabular}{l} 
Farmer's Practice \\
\hline
\end{tabular} & 40751 & 59559 & 18808 & 0.46 \\
\hline
\end{tabular}


Fig.1 Effect of various treatments on grain yield and straw yield of wheat

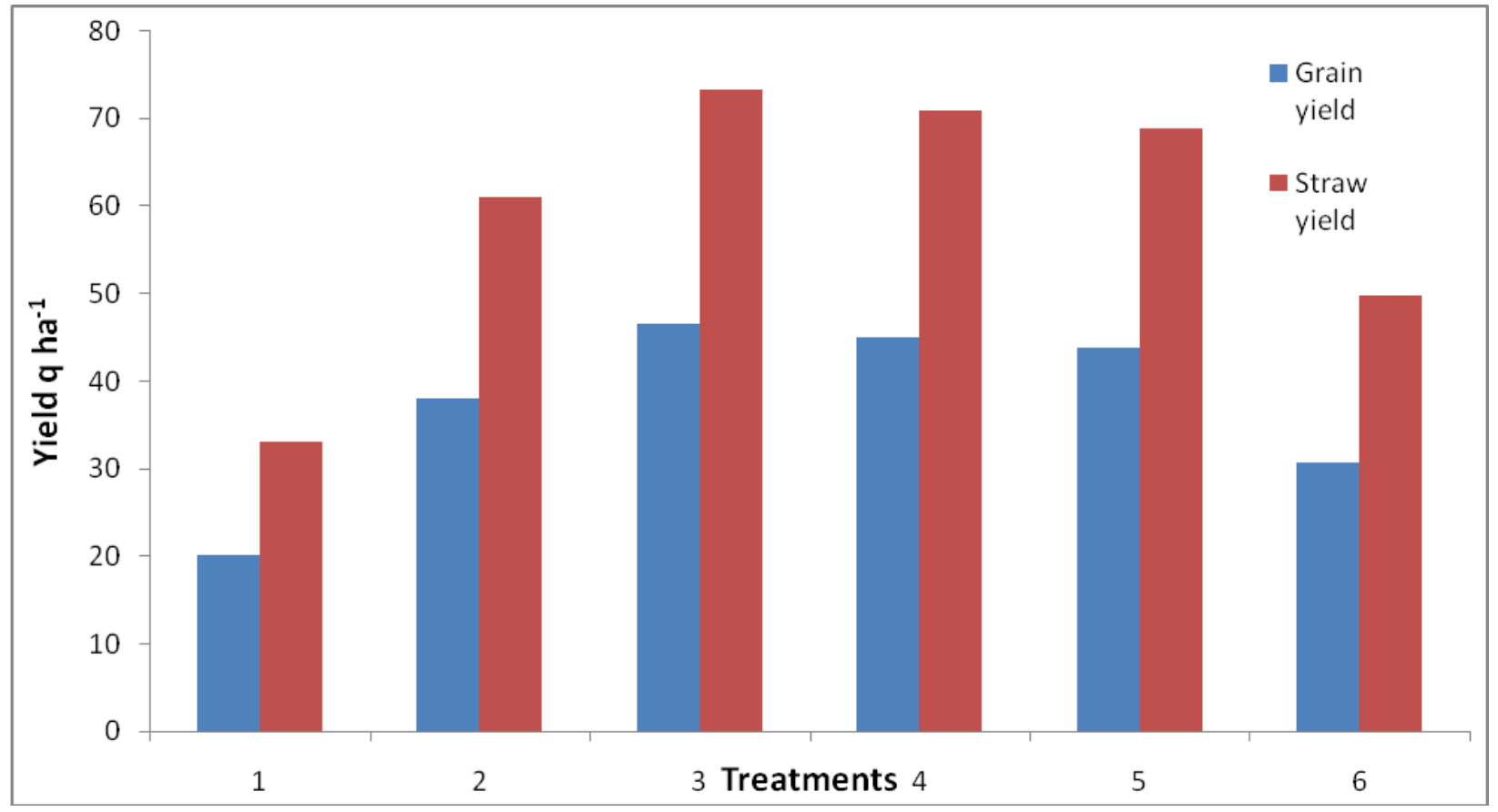

Fig.2 Effect of various treatments on available nitrogen, phosphorus and potassium in soil

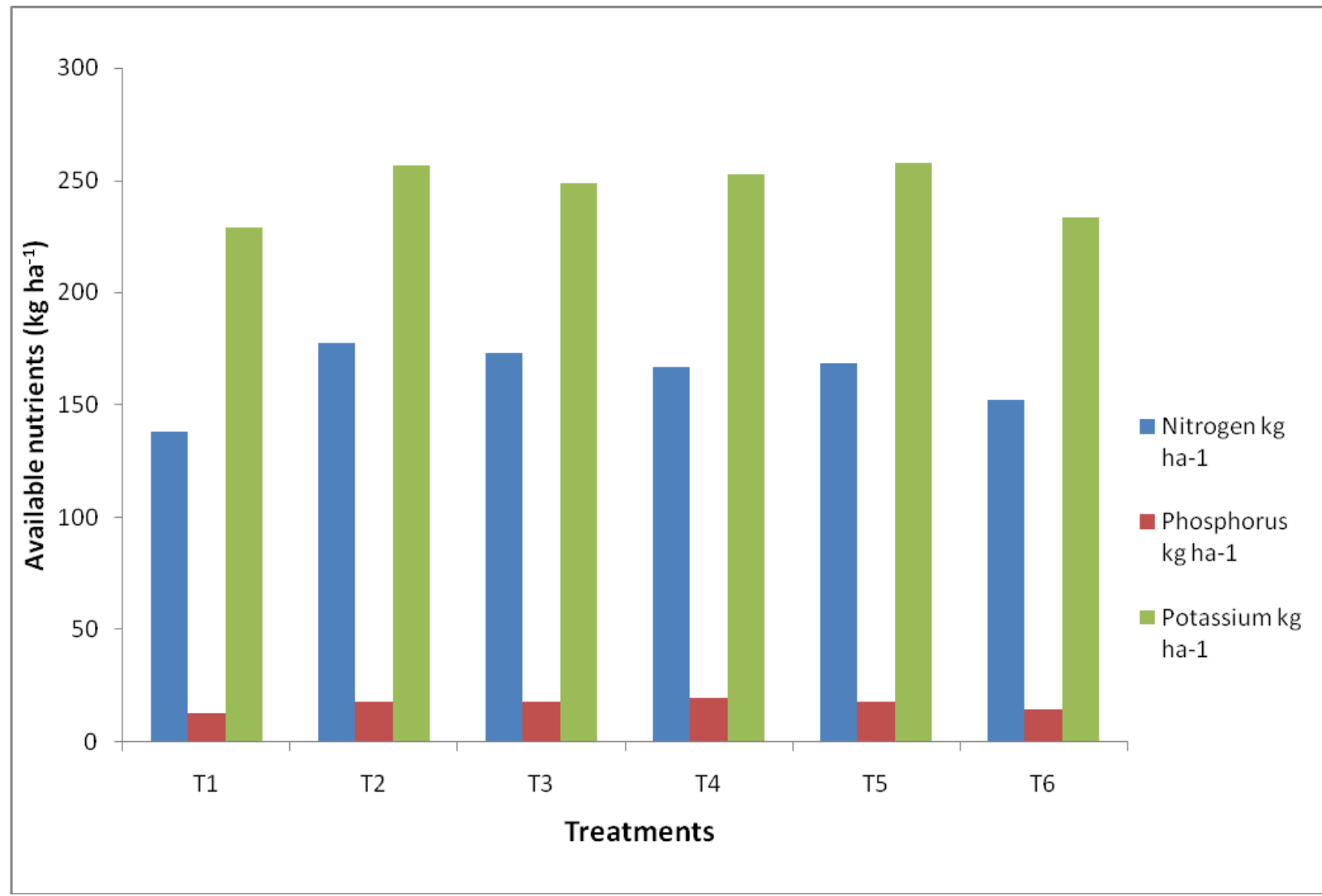


Fig.3 Effect of various treatments on available sulphur, zinc and boron in soil

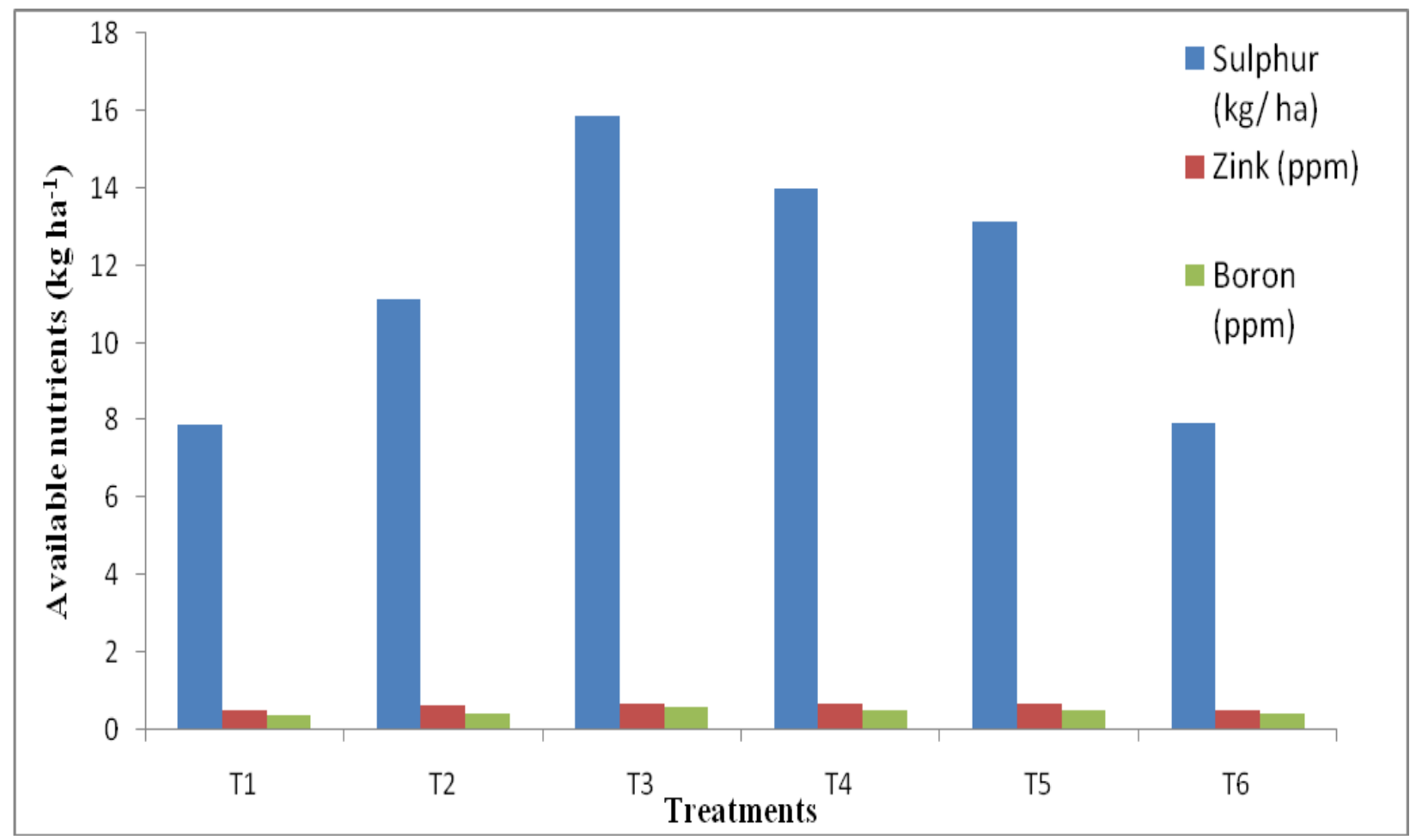

Fig.4 Effect of various treatments on uptake of N, P and K by wheat crop

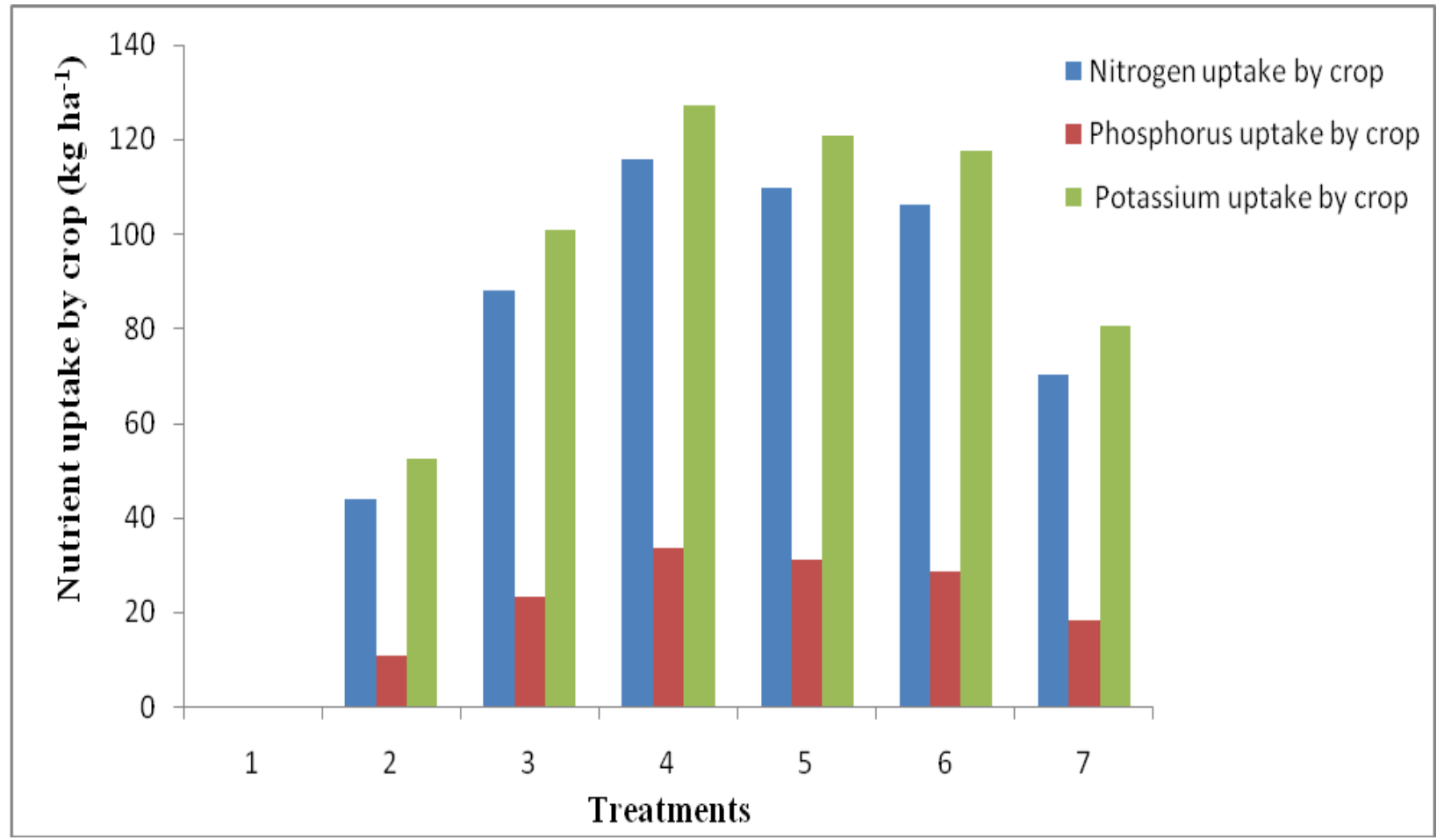


Fig.5 Effect of various treatments on uptake of S, Zn and B by wheat crop

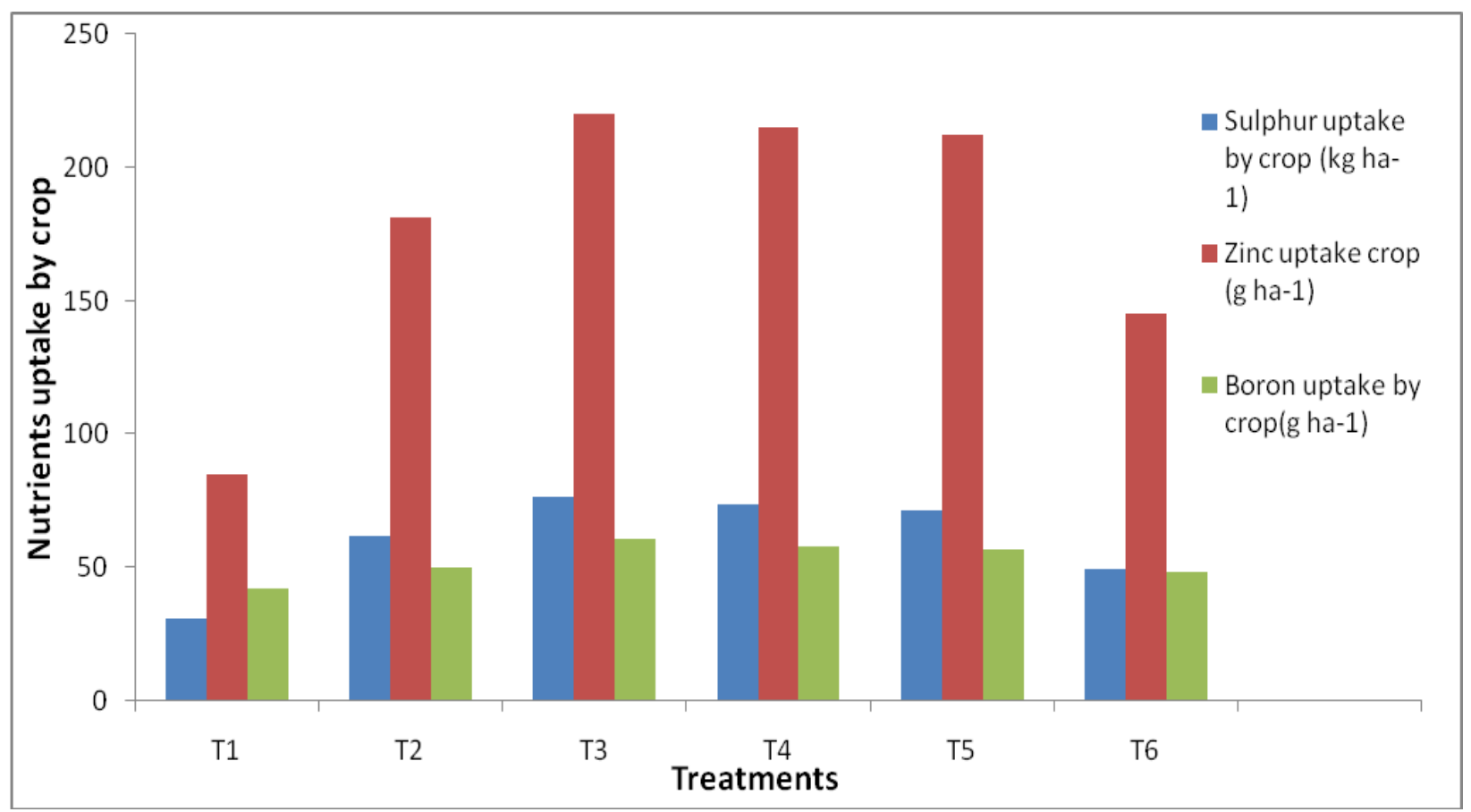

The maximum gross income was recorded with treatment $\mathrm{T}_{3}$ (Rs. $89618 \mathrm{ha}^{-1}$ ) followed by $\mathrm{T}_{4}$ (Rs. $86495 \mathrm{ha}^{-1}$ ) and T $\mathrm{T}_{5}$ (Rs. $84342 \mathrm{ha}^{-1}$ ) and the lowest gross return was recorded with treatment $\mathrm{T}_{1}$ (Rs. $39037 \mathrm{ha}^{-1}$ ). The maximum gross return with $\mathrm{T}_{3}$ was due to the higher increment in yield value as compared to value of input required to apply nutrients in crop. The highest net return was recorded with treatment $\mathrm{T}_{3}$ (Rs. $43828 \mathrm{ha}^{-1}$ ) followed by $\mathrm{T}_{4}$ (Rs. $39078 \mathrm{ha}^{-1}$ ) and $\mathrm{T}_{5}$ (Rs. $36926 \mathrm{ha}^{-1}$ ) and the lowest gross return was recorded with treatment $\mathrm{T}_{1}\left(\right.$ Rs.2507 ha $\left.\mathrm{ha}^{-1}\right)$. The highest benefit: cost ratio (0.95) was obtained under $\mathrm{T}_{3}$ and next best treatments were $\mathrm{T}_{4}(0.82)$ and $\mathrm{T}_{5}(0.78)$. The lowest benefit: cost ratio (0.07) was obtained under treatment $T_{1}$ (control). Similar findings were found in results of Singh et al., (2017), Dwivedi et al., (2014) and Kumar et al., (2009) (Table 4).

Therefore, based on results obtained in this experiment it can be safely concluded that by use of soil test-based recommendation or customized fertilizers we can get maximum grain and straw yield and check the indiscriminate and imbalanced use of chemical fertilizers. The maximum net return and benefit: costs were achieved under those treatments where nutrients applied on soil test-based recommendation. Application of soil test-based recommendation $(\mathrm{N}, \mathrm{P}, \mathrm{K}, \mathrm{S}$, $\mathrm{Zn}$ and $\mathrm{B}$ ) or customized fertilizer sustaining soil fertility, productivity and improved soil health.

\section{References}

Ananda, N., and Patil, B. N. 2005. Effect of Micronutrients ( $\mathrm{Zn}$ and $\mathrm{Fe}$ ) and Time of Nitrogen Application on Growth and Yield of Durum Wheat. Karnataka $J$. Agric. Sci. 18(3): 604-608.

Barthwal, A., Bhardwaj, A.K., Chaturvedi, S. and Pandiraja, T. 2013. Site specific NPK recommendation in wheat (Triticum aestivum L.) for sustainable crop and soil productivity in Mollisols of tarai region. Indian J. of Agronomy 58(2): 208-214. 
Chopra, R., Sharma, M., Sharma, S.K., Nepalia, V., Jain, H.K. and Singh, A. 2016. Effect of integrated nutrient management on growth and yield of wheat (Triticum aestivum L.) in haplustipts. 7(3): 622-628.

Choudhary, P., Jhajharia, A. and Kumar, R. 2014. Influence of sulphur and zinc fertilization on yield, yield components and quality traits of soybean (Glycine max L.). The Bioscan. 9(1): 137-142.

Chuhan, L., Ping H., Mirasol F.P., Adrian M.J., Jiyun J., Xinpeng Xu, Shicheng., Z. Shaojun, Q. and Wei Z. 2013. Establishing a scientific basis for fertilizer recommendations for wheat in China: Yield response and agronomic efficiency. Field Crops Res. 140: 1-8.

Das, K., Medhi, D. N. and Guha, B. 2003. Application of crop residues in combination with chemical fertilizers for sustainable productivity in rice (Oryza sativa) wheat (Triticum aestivum L.) system. Indian J. Agronomy 48(1): 8-11.

Dewal, G.S. and Pareek, R.G. 2014. Effect of phosphorus, sulphur and zinc on growth, yield and nutrient uptake of wheat (Triticum aestivum L.). Indian Journal of Agronomy, 49 (3): 160-162.

Dwivedi, S.K., Meshram, M. R. and N. Pandey 2014. Response of customized fertilizer on wheat (Triticumaestivum L.) under Chhattisgarh condition. An International Quarterly Journal of Life Sciences, 9(4): 1509-1512.

Gibbson, R. S. 2006. Zinc: the missing link in combating

micronutrient malnutrition in developing countries. Proceedings of the Nutrition Society, University of East Anglia, Norwich, June 28 - July 1, 2005.

Goswami, R. 2007. Response of wheat (Triticum aestivum L.) to nitrogen andzinc application. Ann. Agric. Res. New Series. 28(1): 90-91.
Goyal, S.K. and singh, J.P. 2002. Demand versus supply of food grains in India Implications to food security. Paper presented at the $13^{\text {th }}$ International farm management congress, Wageningen, The Netherlands.

Hegde, D. M., Sudhakara Babu, S. N. and Murthy, I. Y. L. N. 2007. Role of Customized Fertilizers in the Improvement of Productivity of Different Crops and Cropping Systems. In Proceedings of national seminar on 'Standards and technology of value added /fortified /customized fertilizers as a source of plant nutrients.(ICAR- IISS, Bhopal, India).

Khan, M., Fuller, M. and Baloch, F. 2008. Effect of soil applied Zinc sulphate on wheat (Triticum aestivum L.) grown on a calcareous soil in Pakistan. Cereal Res. Communications. 36(4).110-113.

Kumar, R., N. K. Mehrotra, B. D. Nautiyal, P. Kumar and P. K. Singh 2009. Effect of copper on growth, yield and concentration of $\mathrm{Fe}, \mathrm{Mn}, \mathrm{Zn}$ and $\mathrm{Cu}$ in wheat (Triticum aestivum). J.Environ. Biol. 30(4):485-488.

Mandal, D., Mandal, S. and Chattopadhyay, G. N. (2004). Soil test-based management of nutrient stress for rice cultivation in red and lateritic soils. Indian Agriculturist. 48(1\&2): 15-18.

Mattean, P.P.J., Schmidt, J.W. and Johnson, V.A. 1970. Screening for high lysine content in wheat. Cereal Sci. today 15:409.

Milapchand 1969. M.Sc.(Ag). Thesis Punjab Agricultural University Ludhiana. Scotta, U. M. Spitzenertragesche. BanfiSpurenelementamangelDLG Mitterllungen95(22): 1280-82.

Pandey, N., Verma, A. K., Anurag and Tripathi, R. S. 2007. Integrated nutrient management in transplanted hybrid rice (Oryza sativa). Indian J. Agronomy. 52(1): 40-42. 
Patel, K. P. and Singh, M. V. 2010. Management of Multi micronutrients deficiencies for enhancing yield of crops. World Congress of Soil Science: Soil solutions for a changing world, Proceeding. pp. 129-132.

Rakshit, R., Rakshit, A. and Das, A. 2012. Customized fertilizers: Marker in fertilizer revolution. Inter. J. Agri. Envi. and Biotec.5(1): 67-75.

Rather, S. A., Sharma, N. L. 2009. Effect of integrated nutrient management (INM) in wheat on soil properties and fertility status. Asian J. of Soil Sci.,4(1): 55-57.

Reddy, M. G. B., Hebbera, M. Patil, V. C. and Patil, S. G. 2009. Response of transplanted rice to level and timing of NPK application, effect of growth, grain yield and economics. An Asian J. Soil
Sciencec4(2): 248-53.

Rekhi, R. S., Benbi, D. K. and Singh, B. 2000. Effect of fertilizers and organic manures on crop yields and soil properties in rice-wheat cropping system. J. Agriculture Research. pp. 1-6

Shekhon, B. S., Kaur, S. and Singh, P. 2012. Evaluation of a customized fertilizer on wheat. Indian J. Ecol. 39(1): 71-75.

Singh, B.B., Biswas, B.C. and Jat, G. 2012.Customized fertilizers, Indian Journal of fertilizers 8(4), pp 74-78.

Singh, V. 2006. Productivity and economics of rice (Oryza sativa) wheat (Triticum aestivum L.) cropping system under integrated nutrient management cropping system supply system in recently reclaimed sodic soil. Indian $J$. Agronomy. 51(2): 81-84.

\section{How to cite this article:}

Anand Singh, Neeraj Kumar, U.P. Shahi, Bhavya Raj Pandey, Pramod Kumar, Prashant Deo Singh and Singh, R.P. 2019. Evaluation of Customized Fertilizers in Respect to Yield, Soil Nutrients Status, Uptake and Economics of Wheat (Triticum aestivum L.) under Eastern Uttar Pradesh. Int.J.Curr.Microbiol.App.Sci. 8(03): 883-894. doi: https://doi.org/10.20546/ijcmas.2019.803.106 